\title{
URGENSI PEMERIKSAAN AHLI JIWA DALAM KASUS KEKERASAN PSIKIS DALAM RUMAH TANGGA
}

Kajian Putusan Nomor 173/Pid.Sus/2014/PN.Lmj

\section{THE URGENCY OF PSYCHIATRIC EXAMINATION IN A CASE OF DOMESTIC EMOTIONAL ABUSE}

\author{
An Analysis of Court Decision Number 173/Pid.Sus/2014/PN.Lmj \\ Y. A. Triana Ohoiwutun \& Surjanti \\ Fakultas Hukum Universitas Jember \\ Jl. Kalimantan No. 37 Tegalboto, Jember 68121 \\ E-mail: anaohoiwutun@ymail.com; surjanti.unita@gmail.com
}

Naskah diterima: 15 Januari 2018; revisi: 13 November 2018; disetujui: 6 Desember 2018

http://dx.doi.org/10.29123/jy.v11i3.300

\section{ABSTRAK}

Putusan Nomor 173/Pid.Sus/2014/PN.Lmj memutus perkara tindak pidana kekerasan psikis dalam rumah tangga yang tidak didasarkan pada keterangan ahli jiwa. Tindak pidana kekerasan psikis dalam Undang-Undang Nomor 23 Tahun 2004 tentang Penghapusan Kekerasan Dalam Rumah Tangga diformulasikan sebagai delik materiil, dan adanya hubungan kausal antara perbuatan pelaku yang berakibat pada trauma psikis korban itulah yang seharusnya dapat dibuktikan. Fokus permasalahan yang dikaji meliputi urgensi keterangan ahli jiwa dalam Putusan Nomor 173/Pid.Sus/2014/PN.Lmj, dan hubungan antara pemeriksaan ahli jiwa dengan tindak pidana kekerasan psikis dalam rumah tangga. Penelitian ini menggunakan metode yuridis normatif. Data penelitian dianalisis secara kualitatif. Putusan Nomor 173/Pid.Sus/2014/PN.Lmj tidak berbasis pada pemeriksaan ahli jiwa, padahal hanya ahli jiwa yang dapat menguji secara ilmiah kebenaran adanya trauma psikis. Pemeriksaan ahli jiwa dapat diberikan oleh psikolog atau psikiater untuk tujuan menemukan kebenaran materiil. Urgensi pemeriksaan ahli jiwa terhadap korban kekerasan psikis dalam rumah tangga,
\end{abstract}

bertujuan untuk menentukan adanya hubungan kausal antara perbuatan terdakwa dengan trauma psikis korban, dan adanya hubungan kausal antara trauma psikis sebagai akibat perbuatan terdakwa itulah yang mengindikasikan adanya kesalahan yang berkorelasi dengan pertanggungjawaban pidana dalam kasus kekerasan psikis dalam rumah tangga.

Kata kunci: ahli jiwa, kekerasan psikis, kekerasan rumah tangga.

\section{ABSTRACT}

Decision Number 173/Pid.Sus/2014/PN.Lmj proceeds a case of psychological domestic violence that are not based on information from psychologists. Crime of emotional abuse in Law Number 23 of 2004 concerning the Elimination of Domestic Violence is formulated as substantive offense, and the causal relationship between the offender's conduct resulting in psychological trauma of the victim should be proven. The focus of the problem includes the urgency of the psychiatrist's information in Decision Number 173/Pid.Sus/2014/PN.Lmj, and the correlation between the examination of psychiatrists 
and criminal acts of domestic emotional abuse. This is a normative juridical method research with qualitative data analysis. Decision Number 173/Pid.Sus/2014/ PN.Lmj is not based on psychiatric examinations, whereas, only psychologists can scientifically examine the truth of psychological trauma. Psychiatric examination can be provided by a psychologist for the purpose of finding the substantial truth. The urgency of psychiatric examination on the victim of domestic emotional abuse aims to determine the causal relationship between the criminal act of the defendant and the psychological trauma of the victim; and the causal relationship between psychological traumas as a result of the defendant's crime indicates an error that correlates with criminal liability in such cases.

Keywords: psychiatrist, emotional abuse, domestic abuse.

\section{PENDAHULUAN}

\section{A. Latar Belakang}

Prinsipnya Pancasila dan UUD NRI 1945 memberikan jaminan hak pada setiap warga negara untuk mendapatkan rasa aman dan bebas dari segala bentuk kekerasan. Konsiderans sebagai dasar pembentukan Undang-Undang Nomor 23 Tahun 2004 tentang Penghapusan Kekerasan Dalam Rumah Tangga menyebutkan, bahwa segala bentuk kekerasan, terutama kekerasan dalam rumah tangga, merupakan pelanggaran hak asasi manusia dan kejahatan terhadap martabat kemanusiaan serta bentuk diskriminasi yang harus dihapus.

Merujuk pada konsiderans Undang-Undang Nomor 23 Tahun 2004, membahas permasalahan kekerasan dalam rumah tangga sama halnya membahas pelanggaran hak asasi manusia, dan membahas Putusan Nomor 173/Pid.Sus/2014/ PN.Lmj sama halnya kita peduli dengan kejahatan terhadap martabat kemanusiaan, apalagi kekerasan itu dilakukan oleh seorang anak terhadap ibu kandungnya.

Putusan Nomor 173/Pid.Sus/2014/PN.Lmj memeriksa perkara seorang terdakwa dewasa (usia 20 tahun) bernama AW. Putusan Pengadilan Negeri Lumajang tanggal 13 Juli 2015 memutus AW dipidana karena terbukti bersalah melakukan tindak pidana kekerasan dalam rumah tangga sebagaimana ditentukan di dalam UndangUndang Nomor 23 Tahun 2004. Kasus posisi bermula dari AW yang terbukti secara sah melakukan tindak pidana kekerasan dalam rumah tangga pada tanggal 9 Januari 2015 sekitar pukul 19.30 WIB. Kekerasan dilakukan oleh AW terhadap saksi korban, yaitu S (ibu kandung AW).

Penuntut umum dalam Putusan Nomor 173/Pid.Sus/2014/PN.Lmj mengajukan dakwaan secara alternatif, yaitu dakwaan kesatu bahwa terdakwa AW pada tanggal 9 Januari 2015 sekira pukul 19.30 WIB atau setidak-tidaknya pada suatu waktu dalam tahun 2015 bertempat di rumah orangtua terdakwa di Dusun Krajan, Desa Selok Awar-awar, Kecamatan Pasirian, Kabupaten Lumajang, ketika itu terdakwa AW pulang dari sebuah kafe dan meminta uang pada D (kakek terdakwa AW), tetapi dilarang oleh S. Adanya larangan dari ibunya tersebut, yang membuat terdakwa AW marah dan kemudian mengambil sebilah sabit yang berada di dapur lalu diacungkannya pada $\mathrm{S}$.

D yang menyaksikan peristiwa tersebut, kemudian memeluk AW dari belakang, yang pada saat itu AW sudah membawa sabit dan hendak membacok S. Dari fakta yang terungkap di persidangan, D meminta pada $\mathrm{S}$ untuk segera 
berlari menyelamatkan diri. Kemudian terdakwa AW ke luar rumah, dan didatangi oleh saksi $P$ yang berusaha menenangkan terdakwa AW, dan selanjutnya terdakwa AW melempar sabit tersebut dan meninggalkan rumah. Akibat dari perbuatan terdakwa AW, saksi korban S dibayangi rasa ketakutan dan merasa jiwanya terancam.

Berdasarkan dakwaan penuntut umum yang dibuat secara alternatif, perbuatan terdakwa AW diancam: kesatu, Pasal 5 huruf b jo. Pasal 45 ayat (1) Undang-Undang Nomor 23 Tahun 2004; atau dakwaan kedua Pasal 355 ayat (1) ke-1 KUHP. Konsekuensi yuridis dakwaan alternatif adalah hakim tidak terikat pada satu dakwaan, namun hakim memiliki keleluasaan untuk memilih alternatif di antara dua perbuatan yang didakwakan tersebut.

Fakta yang terungkap di persidangan, hakim menyatakan bahwa dakwaan alternatif kesatu yang terbukti secara sah dan meyakinkan, sehingga terdakwa AW haruslah dibebaskan dari dakwaan kedua. Dakwaan alternatif kesatu Pasal 5 huruf b jo. Pasal 45 ayat (1) Undang-Undang Nomor 23 Tahun 2004 unsur-unsurnya meliputi: 1) setiap orang; dan 2) melakukan perbuatan kekerasan psikis dalam lingkup rumah tangga.

Perbuatan terdakwaAW yang terbukti secara sah dan meyakinkan sebagaimana disebutkan dalam dakwaan kesatu, yaitu melakukan perbuatan melanggar "kekerasan psikis dalam rumah tangga" terhadap S ibu kandungnya. Hakim dalam Putusan Nomor 173/Pid.Sus/2014/PN.Lmj menjatuhkan sanksi pidana penjara selama lima bulan. Dakwaan penuntut umum, yaitu melanggar Pasal 5 huruf b jo. Pasal 45 ayat (1) UndangUndang Nomor 23 Tahun 2004.

Pasal 5 huruf b Undang-Undang Nomor 23 Tahun 2004 yang diformulasikan sebagai delik materiel, menentukan kualifikasi larangan perbuatan kekerasan psikis dalam rumah tangga. Konsekuensi yuridis formulasi delik yang dirumuskan secara materiel, mensyaratkan adanya akibat dari perbuatan yang dilarang haruslah dapat dibuktikan. Hal yang menarik untuk dikaji dari Putusan Nomor 173/Pid.Sus/2014/PN.Lmj adalah adanya akibat dari kekerasan psikis yang dilakukan oleh terdakwa AW terhadap S justru tidak dibuktikan dalam pemeriksaan perkara.

Dalam konteks unsur perbuatan kekerasan psikis dalam lingkup rumah tangga, adanya akibat ketakutan, hilangnya rasa percaya diri, hilangnya kemampuan untuk bertindak, rasa tidak berdaya, dan/atau penderitaan psikis berat, seharusnya dapat dibuktikan dalam Putusan Nomor 173/ Pid.Sus/2014/PN.Lmj. Secara ilmiah, adanya penderitaan psikis berat korban itulah yang penting untuk dijelaskan oleh ahli jiwa dalam pembuktian perkara, namun demikian, penentuan adanya kekerasan psikis dalam rumah tangga justru tidak diberikan oleh ahli jiwa, dan hakim dalam pertimbangannya tidak menyebutkan pentingnya keterangan ahli jiwa dalam kasus kekerasan psikis dalam lingkup rumah tangga.

Tindak pidana kekerasan psikis yang dilakukan oleh seorang anak terhadap ibunya jelas perbuatan yang tidak etis dan tidak bermoral, sebagaimana dikemukakan oleh Santoso (2014: 92), bahwa antara etis atau moral, hukum dan keadilan merupakan suatu rangkaian yang tidak terpisahkan untuk menciptakan tercapainya kedamaian dan kebahagiaan pada setiap orang.

Perbuatan terdakwa AW memang tidak bermoral, bahkan patut dikecam, dan rasa keadilan yang harus diperoleh semua pihak sudah seharusnya dapat diuji kebenaran materielnya melalui mekanisme pemeriksaan perkara pidana 
oleh hakim. Hakimlah ujung tombak penegakan hukum di Indonesia yang seharusnya berperan serta dalam mewujudkan keadilan yang berbasis pada penemuan kebenaran materiel dalam setiap pemeriksaan perkara pidana, namun demikian trauma psikis korban sebagai akibat dari perbuatan terdakwa AW justru tidak dibuktikan oleh ahli jiwa dalam pemeriksaan Putusan Nomor 173/Pid.Sus/2014/PN.Lmj. Hakim memang tidak keliru, karena KUHAP menganut sistem pembuktian negatief wettelijk bewijs, di mana dalam memutus perkara hakim harus yakin atas kesalahan terdakwa. Dalam pertimbangan yang memberatkan, hakim memang meyakini adanya trauma korban yang disebabkan oleh perbuatan terdakwa, namun demikian keyakinan hakim tidak berbasis pada keterangan ahli jiwa.

Undang-Undang Nomor 23 Tahun 2004 sebagai dasar hukum dalam setiap kasus kekerasan dalam rumah tangga memformulasikan ruang lingkup perbuatan "kekerasan psikis" sebagai delik materiel, sehingga pemeriksaan ahli jiwa bersifat conditio sine qua non. Fenomena tidak adanya keterangan ahli jiwa dalam pembuktian kasus kekerasan psikis dalam rumah tangga perlu dicermati dan dikritisi dalam pemeriksaan Putusan Nomor 173/Pid.Sus/2014/ PN.Lmj, dan dalam kajian ini penulis tertarik menyandingkannya dengan Putusan Nomor 79/ PID.SUS/2015/PT.MDN dan Putusan Nomor 84/ Pid.Sus/2017/PN.Kng.

\section{B. Rumusan Masalah}

Merujuk pada beberapa permasalahan terkait dengan Putusan Nomor 173/Pid. Sus/2014/PN.Lmj sebagaimana dikemukakan dalam latar belakang masalah, fokus utama permasalahan yang perlu dikaji khususnya dalam rangka penemuan kebenaran materiel adalah bagaimanakah hubungan kausal antara keterangan ahli jiwa dengan kekerasan psikis dalam rumah tangga dalam pembuktian Putusan Nomor 173/Pid.Sus/2014/PN.Lmj?

\section{Tujuan dan Kegunaan}

Tujuan yang ingin dicapai dengan fokus penelitian mengenai Putusan Nomor 173/Pid. Sus/2014/PN.Lmj adalah untuk memahami dan menganalisis mengenai urgensi pemeriksaan ahli jiwa dalam kasus perkara kekerasan psikis dalam rumah tangga, khususnya terkait dengan upaya untuk menemukan kebenaran materiel sebagai kebenaran yang dituju dalam setiap pemeriksaan perkara pidana; untuk itu, adanya interaksi dan dependensi antara keterangan ahli jiwa dengan tindak pidana kekerasan psikis dalam rumah tangga menempati posisi yang penting dalam pembuktian perkara.

Manfaat dan kegunaan kajian mengenai Putusan Nomor 173/Pid.Sus/2014/PN.Lmj adalah secara teoritis diharapkan dapat memberikan sumbangan pemikiran secara filosofis konseptual mengenai pentingnya pembuktian yang berbasis pada kebenaran ilmiah, sedangkan secara praktis diharapkan dapat digunakan oleh aparat penegak hukum dalam mengambil keputusan mengenai pentingnya pemeriksaan kejiwaan, baik pada tingkat penyelidikan dan penyidikan perkara maupun pada tahap penuntutan dan pemeriksaan pengadilan, khususnya dalam menangani kasus-kasus yang berhubungan dengan perkara kekerasan psikis dalam rumah tangga.

\section{Tinjauan Pustaka}

Pembedaan delik ke dalam bentuk delik formal dan delik materiel tidak terlepas dari 
makna yang terkandung dari istilah "perbuatan." Menurut Hiariej (2016: 136), dalam istilah perbuatan mengandung dua hal, yaitu kelakuan atau tindakan dan akibat; agar mudah dipahami dapatlah dikatakan bahwa delik formal adalah delik yang menitikberatkan pada tindakan; sedangkan delik materiel adalah delik yang menitikberatkan pada akibat. Lebih lanjut Hiariej (2016: 166) menyatakan bahwa: "de leer van de causaliteit atau teori hubungan kausalitas teramat penting dalam menentukan pertanggungjawaban untuk delik-delik yang dirumuskan secara materiel, karena akibat yang ditimbulkan merupakan unsur delik."

Menurut Moeljatno (Sofian, 2018: 146), dari konsepsi ajaran kausalitas itu terletak dalam lapangan lahir, yaitu hubungan yang dapat dirasakan oleh pancaindra dan berada di area kesalahan; sedangkan ajaran kausalitas sebagai faktor penyebab yang menentukan ukurannya menggunakan akal atau logika; suatu kelakuan dapat ditentukan sebab dari suatu akibat jika dengan adanya kelakuan tadi dan mengingat kompleks keadaan setelah terjadinya akibat (post factum) ternyata menurut logika menurut akal dapat dipastikan bahwa keadaan lalu berubah menuju kepada timbulnya akibat.

Dalam alasan pertimbangannya UndangUndang Nomor 23 Tahun 2004 menyatakan, bahwa korban kekerasan dalam rumah tangga, kebanyakan adalah perempuan, harus mendapat perlindungan dari negara dan/atau masyarakat agar terhindar dan terbebas dari kekerasan atau ancaman kekerasan, penyiksaan, atau perlakuan yang merendahkan derajat dan martabat kemanusiaan.

Reber \& Reber (2010: 764) dalam Kamus Psikologi menyebutkan, bahwa psikis menurut perspektif kata sifat dimaknai secara umum dan longgar, berkaitan dengan pikiran yang sifatnya mental, dan/atau pribadi, dan dimensi kepribadian; sedangkan trauma psikis, merupakan sebuah istilah umum yang digunakan bagi pengalaman psikologis menyakitkan apapun, biasanya digunakan dengan implikasi kalau pengaruh pengalaman bertahan lama dan bahwa ia mengganggu fungsi-fungsi yang normal.

Pasal 1 angka 1 Undang-Undang Nomor 23 Tahun 2004 menentukan, bahwa kekerasan dalam rumah tangga adalah setiap perbuatan terhadap seseorang terutama perempuan, yang berakibat pada timbulnya kesengsaraan atau penderitaan secara fisik, seksual, psikologis, dan/atau penelantaran rumah tangga termasuk ancaman untuk melakukan perbuatan, pemaksaan, atau perampasan kemerdekaan secara melawan hukum dalam lingkup rumah tangga. Merujuk pada Pasal 1 angka 1 Undang-Undang Nomor 23 Tahun 2004, formulasi Pasal 5 menentukan ada empat bentuk perbuatan kekerasan dalam rumah tangga, yaitu: kekerasan fisik, kekerasan psikis, kekerasan seksual, dan penelantaran rumah tangga.

Ruang lingkup kekerasan psikis sebagai fokus dalam penulisan ini, ditentukan di dalam Pasal 7 Undang-Undang Nomor 23 Tahun 2004 adalah perbuatan yang mengakibatkan ketakutan, hilangnya rasa percaya diri, hilangnya kemampuan untuk bertindak, rasa tidak berdaya, dan/atau penderitaan psikis berat pada seseorang. Menurut Rodliyah \& Salim (2017: 250), akibat dari perbuatan kekerasan psikis adalah: tidak menimbulkan penyakit, atau halangan untuk menjalankan pekerjaan jabatan, atau mata pencaharian, atau kegiatan sehari-hari.

Adanya akibat dari perbuatan kekerasan psikis haruslah dapat dibuktikan dalam 
pemeriksaan perkara. Dari perspektif hukum, bukti atau bewijs menurut Marwan \& Jimmy (2009: 113) adalah sesuatu yang digunakan untuk menyatakan kebenaran tentang suatu peristiwa. Makna pembuktian tidak dijelaskan di dalam KUHAP, namun Pasal 66 KUHAP menentukan bahwa tersangka atau terdakwa tidak diserahi beban pembuktian. Pasal 183 KUHAP menentukan bahwa: "hakim tidak boleh menjatuhkan pidana kepada seorang kecuali apabila dengan sekurang-kurangnya dua alat bukti yang sah ia memperoleh keyakinan bahwa suatu tindak pidana benar-benar terjadi dan bahwa terdakwalah yang bersalah melakukannya."

\section{Pasal 183 KUHAP mengindikasikan} bahwa sistem pembuktian yang dianut adalah pembuktian berdasar undang-undang secara negatif (negatief wettelijk bewijs), sebagaimana dikemukakan oleh Hiariej (2012: 17), bahwa: "sistem peradilan pidana Indonesia menganut negatief wettelijk bewijs theorie." Adapun alat bukti yang ditentukan dalam rangka pembuktian menurut Pasal 184 ayat (1) KUHAP meliputi: (a) keterangan saksi; (b) keterangan ahli; (c) surat; (d) petunjuk; dan (e) keterangan terdakwa. Keterangan ahli sebagai alat bukti tidak mempunyai kekuatan mengikat, artinya hakim tidak harus meyakini keterangan ahli.

Disebutkan dalam Pasal 1 angka 1 UndangUndang Nomor 23 Tahun 2004, bahwa kekerasan dalam rumah tangga sebagai suatu perbuatan terhadap seseorang terutama perempuan, yang berakibat pada timbulnya kesengsaraan atau penderitaan secara fisik, seksual, psikologis, dan/atau penelantaran rumah tangga. Terkait dengan perbuatan yang berakibat pada timbulnya kesengsaraan psikologis atau kekerasan psikis pada korban dalam kasus kekerasan dalam rumah tangga, maka pemeriksaan ahli jiwa, baik psikolog maupun psikiater sangatlah diperlukan dalam pembuktian mengenai akibat dari perbuatan pelaku. Keterangan psikolog dan/ atau psikiater dapat diberikan secara tertulis atau secara lisan di pengadilan.

Menurut Gerungan (2009: 1) arti psikologi sama dengan ilmu jiwa, karena kata "psikologi" mengandung kata psyche dalam bahasa Yunani berarti jiwa, dan kata logos berarti ilmu. Dengan demikian, istilah ilmu jiwa merupakan terjemahan secara harfiah dari istilah psikologi. Menurut Ohoiwutun (2016a: 114):

"ilmu jiwa kita gunakan dalam arti yang lebih luas daripada istilah psikologi. Ilmu jiwa meliputi segala pemikiran, pengetahuan, tanggapan, dan juga meliputi segala khayalan dan spekulasi mengenai jiwa itu. Psikologi meliputi ilmu jiwa yang diperoleh secara sistematis dengan metodemetode ilmiah. Istilah ilmu jiwa merujuk pada ilmu jiwa pada umumnya; sedangkan psikologi merujuk pada ilmu jiwa yang ilmiah.”

Menurut Djamali (1984: 12), psikologi sebagai ilmu mengenai tingkah laku manusia dalam pelaksanaannya memfokuskan pada tingkah laku individu. Di samping bantuan disiplin psikologi, ilmu psikiatri juga diberdayakan dalam praktik penegakan hukum pidana terkait dengan aspek kejiwaan, baik pemeriksaan terhadap pelaku, maupun korban tindak pidana. Menurut Soewadi (Ohoiwutun, 2016a: 112), peran psikiatri di dalam hukum meliputi:
"membantu lembaga peradilan dalam menentukan kondisi kesehatan mental seseorang, membuat visum et repertum psychiatricum, membuat surat keterangan kesehatan jiwa, sebagai saksi ahli dalam peradilan, memberikan informasi pada masyarakat luas tentang pentingnya pemeriksaan psikiatrik, membantu perlindungan pengobatan, dan perawatan penderita gangguan jiwa." 
Merujuk pendapat mengenai peranan ahli jiwa dalam pemeriksaan perkara pidana, maka bantuan psikolog dan psikiater dalam melakukan pemeriksaan terhadap korban kekerasan psikis dalam rumah tangga semata-mata untuk menemukan kebenaran materiel. Eksistensi psikolog dan psikiater dalam pemeriksaan perkara pidana dapat memberikan kontribusi tersendiri dalam sistem peradilan pidana, dan dalam aplikasinya pilihan ahli jiwa dalam penegakan hukum di Indonesia bergantung pada kewenangan instansi yang bertanggung jawab dalam pemeriksaan perkara.

\section{METODE}

Penulisan ini berbasis pada penelitian hukum normatif, yaitu penelitian yang mengacu pada norma hukum dengan menggunakan data sekunder. Menurut Diantha (2016: 12), metode penelitian hukum normatif meneliti hukum dari perspektif internal dengan objek penelitiannya adalah norma hukum.

Data yang digunakan dalam penelitian terdiri dari bahan hukum yang merupakan data sekunder, yaitu bahan hukum primer, bahan hukum sekunder, dan bahan hukum tersier. Menurut Marzuki (2014: 181 \& 196), "bahan hukum primer merupakan bahan hukum yang mempunyai sifat autoritatif, artinya memiliki otoritas tertentu" dan "bahan hukum sekunder berguna untuk memberikan "petunjuk" ke arah mana peneliti melangkah." Bahan hukum tersier digunakan dalam memberikan berbagai pengertian yang diperlukan untuk memperjelas permasalahan yang berkaitan dengan peristilahan yang memerlukan penjelasan.

Bahan hukum primer yang digunakan berupa peraturan perundangan yang meliputi
Undang-Undang Nomor 8 Tahun 1981 tentang KUHAP, Undang-Undang Nomor 23 Tahun 2004 tentang Penghapusan Kekerasan Dalam Rumah Tangga, Undang-Undang Nomor 48 Tahun 2009 tentang Kekuasaan Kehakiman; dan Putusan Nomor 173/Pid.Sus/2014/PN.Lmj; di samping itu sebagai bahan perbandingan eksistensi pemeriksaan ahli jiwa dalam pemeriksaan perkara kekerasan psikis dalam rumah tangga disertakan pula Putusan Nomor 79/PID.SUS/2015/PT.MDN dan Putusan Nomor 84/Pid.Sus/2017/PN.Kng yang telah berkekuatan hukum tetap.

Isu hukum pada Putusan Nomor 173/Pid. Sus/2014/PN.Lmj adalah isu yang berada pada ranah hukum pidana. Menurut Diantha (2016: 112), pada bidang hukum pidana, minimal harus memahami sifat hukum pidana sebagai hukum prohibitor dengan bentuknya yang khas, yakni tertulis. Putusan Nomor 173/Pid.Sus/2014/ PN.Lmj yang telah berkekuatan hukum tetap dipilih sebagai studi kasus, karena telah adanya sifat autoritatif putusan. Pendekatan kasus yang perlu dipahami oleh peneliti adalah ratio decidendi hakim, sehingga mengambil suatu putusan tertentu.

Menurut Marzuki (2014: 119), ratio decidendi adalah alasan-alasan hukum yang digunakan oleh hakim untuk sampai pada putusannya. Pendekatan kasus terkait dengan Putusan Nomor 173/Pid.Sus/2014/PN.Lmj bukanlah merujuk kepada diktum putusan pengadilan, melainkan merujuk kepada ratio decidendi hakim, yang dalam kajian disandingkan pula dengan Putusan Nomor 79/PID.SUS/2015/ PT.MDN dan Putusan Nomor 84/Pid.Sus/2017/ PN.Kng.

Studi kepustakaan merupakan cara yang ditempuh dalam mengumpulkan data, yaitu 
berupa bahan hukum primer, bahan hukum sekunder, dan bahan hukum tersier. Data dianalisis secara kualitatif, menurut Muhammad (Ohoiwutun, 2015: 9) yaitu dari data yang telah dikumpulkan kemudian di-sistematisir, dinilai berdasarkan ketentuan dan prinsip hukum yang berlaku serta kenyataan yang terjadi.

Fokus penelitian mengenai eksistensi ahli jiwa dalam pemeriksaan kejahatan kekerasan psikis dalam rumah tangga, dianalisis datanya secara deskriptif kualitatif. Analisis data secara deskriptif kualitatif dilakukan dengan cara menjelaskan mengenai urgensi pemeriksaan ahli jiwa, khususnya dalam rangka menemukan kebenaran materiel, yang bermuara pada penentuan adanya kesalahan terdakwa, pertanggungjawaban pidana dan berakhir pada penjatuhan sanksi pidana oleh hakim.

\section{HASIL DAN PEMBAHASAN}

Penjatuhan sanksi di dalam hukum pidana wajib memenuhi syarat-syarat tertentu, yaitu berkaitan dengan hukum pidana materiel dan hukum pidana formal. Hukum pidana formal atau hukum acara pidana merupakan proses yang harus dilalui dalam setiap penegakan hukum pidana. Demi mencapai tujuan pencarian dan penemuan kebenaran materiel, hukum pidana tidak dapat menghindarkan diri dari adanya interaksi dan bahkan dependensi dengan disiplin ilmu lain di luar hukum pidana.

Menurut Sudarto (1986: 106), "tekanan harus diletakkan pada fungsi mencari kebenaran materiil, dan dalam mencari kebenaran itu dilalui jalan yang panjang ialah pemeriksaan kepolisian, kejaksaan, dan akhirnya di sidang pengadilan." Merujuk pada pendapat Sudarto, jalan panjang dalam mencari kebenaran materiel itu, menempatkan posisi pemeriksaan kepolisian sebagai langkah awal yang strategis dalam pemeriksaan perkara pidana.

Sebagaimana disebutkan pada Bab I huruf D, bahwa: "eksistensi psikolog dan psikiater dalam pemeriksaan perkara pidana dapat memberikan kontribusi tersendiri dalam sistem peradilan pidana, dan dalam aplikasinya pilihan ahli jiwa dalam penegakan hukum di Indonesia bergantung pada kewenangan instansi yang bertanggung jawab dalam pemeriksaan perkara." Kontribusi keterangan ahli jiwa dalam pemeriksaan perkara pidana, baik terhadap korban maupun pelaku tindak pidana inilah yang berperan penting dalam menentukan adanya kesalahan dan sifat melawan hukumnya perbuatan. Dalam kasus kejahatan tertentu, diperlukan pemeriksaan ahli jiwa, baik terhadap pelaku maupun korban untuk menentukan hakikat dari perbuatan dan akibatnya. Eksistensi keterangan ahli jiwa berkorelasi dengan penentuan kesalahan dan pertanggungjawaban pidana, sebagaimana dikemukakan oleh Ohoiwutun (2017: 43):

"dalam pertanggungjawaban pidana, ada hubungan erat antara unsur kesalahan dan sifat melawan hukum, dan apabila perbuatan yang dilakukan tidak bersifat melawan hukum, maka perbuatan tersebut tidak dapat dipertanggungjawabkan kepada pelaku. Pada prinsipnya tidak mungkin ada kesalahan tanpa ada unsur melawan hukum. Faktor kesalahan merupakan unsur penting penentu pertanggungjawaban pidana yang harus dibuktikan dalam penegakan hukum pidana."

Dalam pertimbangan hakim yang memberatkan, Putusan Nomor 173/Pid.Sus/2014/ PN.Lmj menyatakan bahwa: "perbuatan terdakwa AW menyebabkan trauma kepada saksi S; dan sebagai seorang anak seharusnya terdakwa menghormati dan menyayangi orang 
tuanya, akan tetapi terdakwa justru mengancam orang tuanya dengan sabit"; di samping itu, dalam pertimbangan yang memberatkan juga dinyatakan: "akibat perbuatan terdakwa tersebut saksi S mengalami trauma dan selalu khawatir apabila tiba-tiba terdakwa kembali melakukan perbuatannya tersebut, sehingga saksi S kemudian melaporkan terdakwa ke Polsek Pasirian.”

Adanya trauma S yang disebabkan karena perbuatan terdakwa AW merupakan unsur kesalahan yang seharusnya dibuktikan dalam pemeriksaan perkara, dan adanya kesalahan inilah yang menjadi "parameter" penentu pertanggungjawaban pidana. Unsur kesalahan sebagai unsur subjektif yang dilakukan oleh terdakwa AW berupa perbuatan "mengancam orang tuanya (S) dengan sabit," adalah perbuatan yang jelas bersifat melawan hukum sebagaimana ditentukan di dalam Undang-Undang Nomor 23 Tahun 2004, dan adanya trauma S inilah yang seharusnya dibuktikan dalam pemeriksaan perkara.

Dalam konteks pembuktian perkara pidana menurut Hiariej (2012: 37), rumusan delik dalam suatu undang-undang, selain merupakan perwujudan asas legalitas, juga memiliki fungsi unjuk bukti. Artinya, yang harus dibuktikan oleh penuntut umum di pengadilan adalah unsur-unsur dalam suatu rumusan delik yang didakwakan kepada tersangka.

Tindak pidana yang dilarang menurut Diantha (2016: 113), harus dirumuskan dengan jelas di dalam pasal-pasal pidana, dan ini mempunyai akibat jika tidak dilarang berarti boleh, larangan harus dirumuskan dengan pasti, tegas, dan jelas. Merujuk pada pendapat Hiariej dan Diantha, jelaslah, bahwa sebagai perwujudan asas legalitas adanya trauma $\mathrm{S}$ inilah yang dilarang dan seharusnya dibuktikan dalam pemeriksaan perkara kekerasan psikis dalam rumah tangga sebagaimana ditentukan di dalam Undang-Undang Nomor 23 Tahun 2004.

Dasar hukum dakwaan penuntut umum adalah Pasal 5 huruf b jo. Pasal 45 ayat (1) Undang-Undang Nomor 23 Tahun 2004. Pasal 5 huruf b menyatakan bahwa: "setiap orang dilarang melakukan kekerasan dalam rumah tangga terhadap orang dalam lingkup rumah tangganya, dengan cara kekerasan psikis." Pasal 45 ayat (1) menyatakan bahwa: "setiap orang yang melakukan perbuatan kekerasan psikis dalam lingkup rumah tangga sebagaimana dimaksud dalam Pasal 5 huruf b dipidana dengan pidana penjara paling lama tiga tahun atau denda paling banyak Rp9.000.000,-”

Dakwaan penuntut umum tidak memperjelas ruang lingkup atau makna dari kekerasan psikis sebagaimana ditentukan di dalam Pasal 7 Undang-Undang Nomor 23 Tahun 2004, padahal rumusan delik dalam suatu undang-undang, selain merupakan perwujudan asas legalitas, juga memiliki fungsi unjuk bukti sebagaimana dikemukakan oleh Hiariej (2012: 37); dan justru adanya perbuatan kekerasan psikis yang dilakukan oleh terdakwa AW itulah yang harus dibuktikan dalam pemeriksaan perkara di pengadilan.

Pasal 7 Undang-Undang Nomor 23 Tahun 2004, menentukan bahwa: "kekerasan psikis sebagaimana dimaksud dalam Pasal 5 huruf b adalah perbuatan yang mengakibatkan ketakutan, hilangnyarasa percaya diri, hilangnyakemampuan untuk bertindak, rasa tidak berdaya, dan/atau penderitaan psikis berat pada seseorang." Pasal 7 diformulasikan secara alternatif limitatif, artinya perbuatan kekerasan psikis yang dilakukan oleh 
pelaku harus meliputi perbuatan yang berakibat pada perasaan ketakutan, hilangnya rasa percaya diri, hilangnya kemampuan untuk bertindak, rasa tidak berdaya, dan/atau penderitaan psikis berat pada korban.

Putusan Nomor 173/Pid.Sus/2014/ PN.Lmj justru tidak membuktikan perbuatan terdakwa AW yang berakibat terjadinya ketakutan, hilangnya rasa percaya diri, hilangnya kemampuan untuk bertindak, rasa tidak berdaya, dan/atau penderitaan psikis berat pada korban S. Pembuktian secara ilmiah adanya akibat dari perbuatan AW diperlukan dalam rangka menemukan kebenaran materiel sebagaimana yang dituju di dalam pemeriksaan perkara pidana. Pembuktian adanya perbuatan AW yang berakibat pada trauma psikis pada $\mathrm{S}$, memerlukan bantuan pemeriksaan ahli jiwa untuk mengungkap suatu kebenaran materiel, dan hanya kebenaran ilmiahlah suatu pembuktian perkara pidana dapat diterima akal sehat.

Pembuktian adanya trauma psikis dalam Putusan Nomor 173/Pid.Sus/2014/PN.Lmj dapat disandingkan dengan Putusan Nomor 79/PID. SUS/2015/PT.MDN yang membatalkan Putusan Nomor 1.255/Pid.B/2014/PN.Mdn, yang mana putusan hakim banding berbasis pada kesimpulan dokter pembuat visum et repertum psychiatricum yang menyatakan bahwa "korban yang mengalami depresi ringan bersifat kemungkinan bukan kesimpulan yang bersifat kepastian, yang berarti masih ada kemungkinan lain, sehingga visum et repertum tidak dapat 100\% (seratus persen) merupakan penyebab hal yang dialami oleh saksi korban."

Putusan Nomor 84/Pid.Sus/2017/PN.Kng berbasis pada keterangan ahli psikologi berdasarkan Surat Keterangan Nomor 228/PPT-
Sancita/I/2017 tanggal 26 Januari 2017 yang menyatakan, bahwa majelis hakim berpendapat bahwa "benar terdakwa telah melakukan perkataan dan perbuatan yang menimbulkan saksi korban tertekan batinnya sehingga mengalami gangguan secara psikis." Putusan Nomor 79/ PID.SUS/2015/PT.MDN dan Putusan Nomor 84/Pid.Sus/2017/PN.Kng secara jelas berbasis pada keterangan ahli jiwa dalam memutus perkara kekerasan psikis dalam rumah tangga, baik dalam menjatuhkan sanksi maupun dalam membebaskan terdakwa.

Pertimbangan hakim dalam Putusan Nomor 173/Pid.Sus/2014/PN.Lmj yang menyatakan bahwa: "perbuatan terdakwa menyebabkan trauma kepada saksi S" tidak didasarkan pada keterangan ahli jiwa, sedangkan trauma itu sendiri dari perspektif ilmu kedokteran dapat ditinjau dari kondisi cedera fisik atau psikis seseorang. Trauma yang berasal dari kata Yunani menurut Reber \& Reber (2010: 999) berarti luka; sedangkan trauma menurut Danis (tt: 635) dalam Kamus Kedokteran, diartikan sebagai luka atau cedera, baik fisik atau psikis.

Dari perspektif ilmu jiwa, sebagaimana disebutkanoleh Reber \& Reber(2010:999), bahwa trauma adalah "sebuah istilah yang digunakan bebas, entah bagi luka fisik yang disebabkan oleh beberapa kekuatan eksternal langsung atau luka psikologis yang disebabkan oleh serangan emosi yang ekstrem." Apabila merujuk pada fakta yang terungkap di persidangan, bahwa terdakwa AW marah, kemudian mengancam dan hendak membacok S dengan menggunakan sabit; namun demikian $\mathrm{S}$ dapat berlari dan menyelamatkan diri.

Fakta yang terungkap di persidangan dalam Putusan Nomor 173/Pid.Sus/2014/PN.Lmj, jelas menggambarkan bahwa tidak terjadi 
pembacokan yang dapat berakibat cedera atau luka fisik, namun demikian perbuatan terdakwa AW berupa serangan emosi yang ekstrem dapat dikategorikan sebagai trauma psikis, atau termasuk dalam lingkup kekerasan psikis dalam rumah tangga. Merujuk pada fakta yang terungkap di persidangan, trauma korban $\mathrm{S}$ sebagaimana pertimbangan hakim yang memberatkan, apabila merujuk pada kamus psikologi, merupakan "luka psikologis" yang disebabkan oleh serangan emosi yang ekstrem dari terdakwa AW.

Mengacu pada pendapat Rodliyah \& Salim (2017: 250) sebagaimana disebutkan pada Bab 1 huruf D, bahwa: "akibat dari perbuatan kekerasan psikis adalah tidak menimbulkan penyakit, atau halangan untuk menjalankan pekerjaan jabatan, atau mata pencaharian, atau kegiatan seharihari"; dan kejahatan kekerasan psikis dalam rumah tangga dirumuskan sebagai delik materiel di dalam Pasal 7 Undang-Undang Nomor 23 Tahun 2004.

Konsekuensi yuridis formulasi delik materiel, yaitu adanya hubungan kausal antara perbuatan terdakwa AW yang berakibat pada terjadinya trauma psikis pada korban $\mathrm{S}$ itulah yang seharusnya dibuktikan. Sebagaimana dikemukakan oleh Hiariej (2016: 166), bahwa hubungan kausalitas, sangatlah penting untuk delik-delik yang dirumuskan secara materiel dan delik-delik yang dikualifikasi oleh akibatnya; hubungan kausalitas berbicara mengenai sebab musabab dari suatu akibat, dan dapat saja suatu akibat muncul dari sekian banyak musabab.

Adanya sebab dari perbuatan terdakwa AW yang mengancam dan hendak membacok telah berakibat pada trauma psikis yang dialami oleh S itulah yang semestinya dapat dibuktikan di dalam pemeriksaan perkara di pengadilan dengan didukung oleh keterangan ahli jiwa. Dengan demikian, melalui pemeriksaan ahli jiwa dapat disimpulkan adanya hubungan kausalitas, yaitu sebab musabab dari perbuatan AW yang telah mengakibatkan trauma psikis pada $\mathrm{S}$, dan trauma psikis itu sendiri memang tidak muncul dari musabab yang lain.

Penyebab terjadinya trauma $\mathrm{S}$ atas tindakan kekerasan yang dilakukan oleh terdakwa AW sebenarnya berkorelasi dengan penentuan pertanggungjawaban pidana dan sanksi yang dapat dijatuhkan oleh hakim. Tindak pidana kekerasan psikis dalam rumah tangga dirumuskan sebagai delik materiel dan dikualifikasikan akibatnya di dalam Pasal 7 Undang-Undang Nomor 23 Tahun 2004. Akibat yang dilarang dalam Pasal 7 adalah adanya rasa ketakutan, hilangnya rasa percaya diri, hilangnya kemampuan untuk bertindak, rasa tidak berdaya, dan/atau penderitaan psikis berat pada seseorang.

Adanya hubungan kausal antara perbuatan terdakwa AW dengan trauma psikis korban inilah yang seharusnya dapat dibuktikan melalui pemeriksaan kejiwaan. Sebagaimana dinyatakan pada Bab I huruf D menurut Hiariej (2016: 166), bahwa: "de leer van de causaliteit atau teori hubungan kausalitas teramat penting dalam menentukan pertanggungjawaban untuk delikdelik yang dirumuskan secara materiel, karena akibat yang ditimbulkan merupakan unsur delik."

Merujuk pada pendapat Hiariej, terkait dengan Putusan Nomor 173/Pid.Sus/2014/ PN.Lmj, akibat perbuatan yang dikualifikasikan adalah meliputi rasa ketakutan, hilangnya rasa percaya diri, hilangnya kemampuan untuk bertindak, rasa tidak berdaya, dan/atau penderitaan psikis berat pada korban S. Unsur utama delik itulah sebagai akibat dari perbuatan 
terdakwa AW, yang tentunya harus dibuktikan melalui mekanisme pemeriksaan ahli jiwa.

Hal ini dapat disandingkan dengan Putusan Nomor 79/PID.SUS/2015/PT.MDN, di mana disebutkan bahwa akibat dari perbuatan terdakwa, saksi korban merasa ditelantarkan dan mengalami depresi ringan sebagaimana dinyatakan dalam Visum et Repertum Psychiatricum Nomor 42/ SK/P/VISUM/X/2013 tanggal 08 Oktober 2013 bahwa korban OS mengalami gangguan campuran depresif ringan. Putusan Nomor 84/Pid.Sus/2017/ PN.Kng berbasis pada Surat Keterangan Psikolog Nomor 228/PPT-Sancita/I/2017 tanggal 26 Januari 2017 menyebutkan bahwa akibat perbuatan terdakwa, saksi korban mengalami beban psikologis berat dikarenakan persoalan rumah tangganya, sehingga memerlukan dukungan psikologis dalam menghadapi dan menyelesaikan perkaranya.

Merujuk pada Putusan Nomor 79/PID. SUS/2015/PT.MDN dan Putusan Nomor 84/ Pid.Sus/2017/PN.Kng yang memutus kasus kekerasan psikis dalam rumah tangga, jelas bahwa hubungan kausal antara perbuatan terdakwa dengan akibatnya berbasis pada keterangan ahli, baik psikiater maupun psikolog; namun demikian Putusan Nomor 173/Pid.Sus/2014/ PN.Lmj tidak berbasis pada keterangan ahli jiwa. Padahal, maksud dari delik materiel sebagaimana dikemukakan oleh Remmelink (Ohoiwutun, 2016b: 77), adalah suatu perbuatan yang menyebabkan konsekuensi-konsekuensi tertentu, di mana perbuatan tersebut kadang tercakup dan kadang tidak tercakup sebagai unsur dalam perumusan tindak pidana.

Putusan Nomor 173/Pid.Sus/2014/PN.Lmj, telah menggambarkan perbuatan terdakwa AW yang menyebabkan $\mathrm{S}$ mengalami trauma psikis atau dalam hal ini telah tercakup dan memenuhi perumusan unsur delik sebagaimana disebutkan di dalam Pasal 5 dan Pasal 7 Undang-Undang Nomor 23 Tahun 2004. Apabila merujuk pada pendapat Remmelink, seseorang dapat dipidana karena melakukan tindak pidana kekerasan psikis dalam rumah tangga, yang secara alternatif limitatif dapat menimbulkan akibat berupa ketakutan, hilangnya rasa percaya diri, hilangnya kemampuan untuk bertindak, rasa tidak berdaya, dan/atau penderitaan psikis berat pada seseorang; dan hal inilah yang seharusnya dibuktikan dalam pemeriksaan Putusan Nomor 173/Pid.Sus/2014/ PN.Lmj.

Hukum acara pidana menganut asas actori incumbit onus probandi, bahwa siapa yang menuntut, dialah yang wajib membuktikannya; dan sebagai kelanjutannya berlaku pula asas actore non probante, reus absolvitur, yaitu apabila tidak dapat dibuktikan, terdakwa harus dibebaskan. Merujuk pada berlakunya asas actori incumbit onus probandi dan asas actore non probante, reus absolvitur dalam pemeriksaan Putusan Nomor 173/Pid.Sus/2014/PN.Lmj, terdakwa AW seharusnya dibebaskan apabila penuntut umum tidak dapat membuktikan adanya trauma psikis yang berbasis pada keterangan ahli jiwa.

Tindak pidana kekerasan psikis dalam rumah tangga, sebagai delik materiel melarang akibat tertentu yang berada pada ranah psikis atau kejiwaan seseorang sebagai akibat dari perbuatan orang lain. Dengan demikian, pentinglah pembuktian adanya hubungan kausal antara perbuatan pelaku yang berdampak psikis pada korban. Tidak adanya pemeriksaan ahli jiwa dalam Putusan Nomor 173/Pid.Sus/2014/ PN.Lmj, tentunya tidak dapat membuktikan kebenaran kondisi kejiwaan korban yang trauma 
psikis. Padahal, adanya hubungan kausal antara perbuatan terdakwa AW beserta akibatnya di dalam perumusan delik materiel, akan berkorelasi dengan pertanggungjawaban pidana.

Posisi penting pemeriksaan kejiwaan oleh ahli jiwa inilah yang justru menentukan terbuktinya unsur-unsur kekerasan psikis perbuatan materiel yang dilakukan oleh terdakwa AW terhadap korban S. Ratio decidendi hakim dalam memutus perkara pidana yang berbasis pada pemeriksaan ahli jiwa, tentunya secara rasional "lebih" dapat diterima semua pihak, sebagaimana Putusan Nomor 79/PID.SUS/2015/ PT.MDN yang membatalkan Putusan Pengadilan Nomor 1.255/Pid.B/2014/PN.Mdn, yang dalam pertimbangannya menyebutkan bahwa pertimbangan majelis hakim yang mendasarkan pada keterangan Ahli Kedokteran Jiwa dalam Visum et Repertum Psychiatricum Nomor 42/SK/P/VISUM/X/2013 bahwa korban OS mengalami depresi ringan mungkin disebabkan beberapa hal lain, yaitu:

1. Kekerasan psikis akibat ditinggal istri dengan membawa anak OS;

2. Status perceraian OS yang sedang banding di pengadilan;

3. Kekhawatiran OS akan terganggunya kejiwaan anak OS yang masih kecil.

Majelis hakim yang mendasarkan Visum et Repertum Psychiatricum Nomor 42/SK/P/ VISUM/X/2013 perbuatan kekerasan psikis adalah pertimbangan yang salah dan keliru; dan pengadilan tinggi tidak sependapat dengan pertimbangan hakim tingkat pertama. Merujuk pada Putusan Nomor 79/PID.SUS/2015/ PT.MDN, jelas bahwa ratio decidendi hakim berbasis pada keterangan ahli jiwa.
Putusan Nomor 173/Pid.Sus/2014/PN.Lmj dalam proses pembuktian, sebenarnya hakim dapat memerintahkan pada penuntut umum untuk dilakukannya pemeriksaan ahli jiwa guna menilai dan menentukan adanya trauma psikis korban sebagai akibat dari perbuatan terdakwa. Kekuasaan hakim yang absolut dalam sistem pembuktian negatief wettelijk bewijs yang dianut KUHAP, tugas hakim bukan hanya menerapkan undangundang; tetapi hakim juga dapat menggunakan interpretative concept dalam pemeriksaan perkara pidana. Kekuasaan hakim yang absolut dalam pemeriksaan perkara, dan dengan diskresi subjektifnya, hakim berkuasa memerintahkan pada penuntut umum untuk melengkapi dakwaannya guna menunjang penemuan kebenaran materiel dalam pembuktian perkara.

Adanya trias di dalam hukum pidana atau tiga permasalahan pokok yang meliputi perbuatan pidana, pertanggungjawaban pidana, dan sanksi. Pada tahap penerapan hukumnya, ketiga hal tersebut juga merupakan isu utama yang terangkum dalam setiap putusan perkara pidana, dalam artian, dalam ruang lingkup pemeriksaan perkara pidana, meliputi: perbuatan apakah yang telah dilakukan oleh terdakwa, bagaimanakah bentuk pertanggungjawaban pidananya, dan akhirnya sanksi apakah yang dapat dijatuhkan terhadap terdakwa.

Perbuatan pidana yang berbasis pada asas legalitas, pertanggungjawaban pidana yang berbasis pada asas kesalahan dan berakhir pada penjatuhan sanksi terangkum dalam setiap putusan perkara pidana. Akhirnya, melalui pertimbangan hakim suatu putusan mendapatkan justifikasinya, dan ratio decidendi yang tercermin dari dasar pertimbangan putusan adalah alasan logis hakim dalam memutus setiap perkara. Terkait dengan dasar pertimbangan dalam 
putusan hakim, menurut Idris, Rachminawati \& Mulyana (Mappiase 2015: 12):

"Pertimbangan hukum putusan hakim, bukan hanya harus logis, rasional, dan ilmiah, melainkan juga sekaligus intuitif irasional. Rasional-ilmiah, artinya hakim harus memiliki kemampuan mengenal dan memahami kenyataan faktanya serta aturan yang berlaku beserta ilmunya; adapun logisintelektual dalam hal ini mengandung arti menerapkan suatu aturan terhadap kasus konkret dengan mengindahkan hukumhukum logika; demikian pula intuitif irasional, berarti kepekaan hati nurani dan perasaan halus mendampingi rasio dan logika sehingga melahirkan keadilan."

Hakikat adanya syarat logis, rasional, dan ilmiah dalam putusan hakim dalam pemeriksaan perkara pidana inilah yang mengindikasikan bahwa perkembangan ilmu pengetahuan lain di luar hukum pidana turut berkontribusi dalam perkembangan hukum pidana, khususnya dalam pembuktian perkara. Syarat logis, rasional, dan ilmiah inilah yang akan menguji kebenaran materiel dengan menerapkan disiplin ilmu lain di luar hukum pidana, bahkan dapat dikatakan ada interaksi dan dependensi ilmu lain dengan hukum pidana. Oleh karena itu, hukum pidana tidak mungkin "meninggalkan" hakikat perkembangan disiplin ilmu lain, khususnya dalam pembuktian perkara.

Ilmu-ilmu forensik menurut Kitaeff (2017: 17), adalah kajian dan praktik penerapan ilmu alam, ilmu fisika, dan ilmu sosial pada resolusi isu-isu hukum. Penggunaan ilmu-ilmu forensik yang logis, rasional, dan ilmiah merupakan pendukung utama tujuan penemuan kebenaran materiel di dalam hukum pidana. Perkembangan disiplin ilmu psikiatri forensik dan psikologi forensik turut berkontribusi dalam menemukan kebenaran materiel yang berbasis pada syarat logis, rasional, dan ilmiah.
Menurut Kitaeff (2017: 18), kesaksian psikologis sering kali mengambil bentuk sindroma atau profil psikologis dan sering disebut soft science (ilmu pengetahuan lunak); sedangkan ilmu-ilmu fisik dilihat sebagai hard science (ilmu pengetahuan keras). Merujuk pada pendapat Kitaeff, yang jelas sebagai soft science, psikologi forensik, dan psikiatri forensik berhubungan dengan aspek-aspek hukum perilaku manusia, karena pada prinsipnya ada titik temu antara hukum dengan psikologi dan/atau psikiatri. Titik temu antara hukum, psikologi dan psikiatri adalah berhubungan dengan tujuannya, yaitu pada kebaikan dan kepantasan dalam berperilaku untuk tercapainya keamanan, ketenteraman, dan kedamaian hidup setiap orang di dalam masyarakat.

Dalam praktik penegakan hukum pidana, penentuan pilihan ahli jiwa terletak sepenuhnya pada aparat penegak hukum, baik penyidik, penuntut umum maupun hakim. Alternatif pilihan ahli jiwa dapat dilakukan melalui pemeriksaan psikiatri forensik yang menjadi kompetensi dokter ahli jiwa atau psikiater; sedangkan pada pemeriksaan psikologi forensik menjadi kompetensi psikolog.

Menurut Soewadi (Ohoiwutun, 2016a: 111), psikiatri forensik (forensic psychiatry) adalah cabang ilmu kedokteran jiwa yang mempunyai fungsi forensik; sedangkan menurut Meliala (2008: 25), psikologi forensik merupakan istilah yang dapat memayungi luasnya cakupan keilmuan psikologi forensik, dan penggunaan istilah psikologi forensik lebih tepat sebagai sebutan payung (umbrella concept) yang dapat merangkul keseluruhan misi bantuan psikologi di dalam hukum, meskipun bantuan psikologi dalam hukum memiliki fokus yang berbeda. 
Menurut Reber \& Reber (2010: 763), praktik aktual psikiater dan psikolog klinis tumpang tindih, namun perbedaan utamanya adalah psikiater lantaran izin medis yang dimilikinya, berhak secara legal memberikan obat kimiawi, sedangkan psikolog klinis tidak.

Merujuk pada pendapat Reber \& Reber, ada kewenangan "lebih" yang dimiliki oleh psikiater sebagai tenaga medis daripada psikolog. Dengan demikian, selama ini tidaklah keliru penerapan pilihan ahli jiwa dalam pemeriksaan perkara pidana yang bergantung sepenuhnya pada "selera" aparat penegak hukum; sebagaimana Putusan Nomor 79/PID.SUS/2015/PT.MDN yang berbasis pada keterangan ahli psikiatri; sedangkan Putusan Nomor 84/Pid.Sus/2017/ PN.Kng berbasis pada keterangan ahli psikologi.

Menurut hemat penulis ketepatan pilihan ahli jiwa, psikiater atau psikolog, seharusnya bergantung pada kasus perkara yang ditangani. Dalam kasus Putusan Nomor 173/Pid.Sus/2014/ PN.Lmj, apabila merujuk pada fakta yang terungkap di persidangan, pemeriksaan ahli jiwa lebih tepat dilakukan oleh psikolog melalui pemeriksaan psikologi forensik.

Berhubungan dengan penyelenggaraan peradilan, menurut Badriyah (2016: 79), hakim melakukan penerapan hukum yang abstrak sifatnya pada peristiwa yang konkret, yang kemudian dari sinilah hakim berperan penting dalam mengaplikasikan hukum dari yang umum dan abstrak dalam menyelesaikan peristiwa hukum yang terjadi di masyarakat.

Merujuk pada pendapat Badriyah, peranan hakim sangatlah strategis dalam menerapkan hukum yang abstrak sebagaimana ditentukan di dalam Pasal 5 dan Pasal 7 Undang-Undang Nomor 23 Tahun 2004, menjadi hukum yang konkret dalam kasus kekerasan psikis dalam rumah tangga.

Menurut Kitaeff (2017: 18), selama 100 tahun terakhir, psikolog dan psikiater telah menganjurkan ditingkatkannya keterlibatan ahli jiwa di ruang sidang dan sistem hukum. Merujuk pada pendapat Kitaeff, jika formulasi undang-undang merumuskan suatu perbuatan ke dalam delik materiel yang "menghendaki" adanya akibat trauma psikis, maka konsekuensi logisnya pemeriksaan kejiwaan oleh ahli jiwa merupakan suatu yang bersifat conditio sine qua non, seharusnya ada dan tidak dapat dihindari.

Pasal 1 angka 1 Undang-Undang Nomor 23 Tahun 2004 menyebutkan bahwa kekerasan dalam rumah tangga sebagai suatu perbuatan terhadap seseorang terutama perempuan, yang berakibat pada timbulnya kesengsaraan atau penderitaan secara fisik, seksual, dan psikologis dan/atau penelantaran rumah tangga termasuk ancaman untuk melakukan perbuatan, pemaksaan, atau perampasan kemerdekaan secara melawan hukum dalam lingkup rumah tangga.

Merujuk pada Pasal 1 angka 1 UndangUndang Nomor 23 Tahun 2004, khususnya formulasi "yang berakibat pada timbulnya kesengsaraan atau penderitaan secara fisik, seksual, dan psikologis," maka penerapan prinsipprinsip dalam ilmu pengetahuan kejiwaan dalam kasus kekerasan dalam rumah tangga (khususnya kekerasan psikis) merupakan suatu "kewajiban" dalam aplikasi hukumnya.

Merujuk pada Pasal 7 Undang-Undang Nomor 23 Tahun 2004 yang memformulasikan mengenai kekerasan psikis adalah: perbuatan yang mengakibatkan ketakutan, hilangnya rasa percaya diri, hilangnya kemampuan untuk bertindak, rasa tidak berdaya, dan/atau 
penderitaan psikis berat pada seseorang. Adanya "penderitaan" psikis berat inilah yang seharusnya memerlukan pemeriksaan ahli jiwa, baik psikiater dan/atau psikolog.

Kasus kekerasan psikis sebagaimana ditentukan di dalam Undang-Undang Nomor 23 Tahun 2004, pemeriksaan psikiater dan/atau psikolog kapasitasnya sebagai ahli jiwa atau secara teknis yuridis dalam rangka mendapatkan keterangan ahli. Jenis keterangan ahli secara garis besar menurut Hiariej (2012: 66) dapat dibedakan menjadi dua, yaitu:

1. Pendapat ahli mengenai suatu permasalahan yang menjadi topik perkara di persidangan atas dasar suatu pengetahuan atau pengalaman ahli yang dinyatakan di persidangan tanpa memerlukan suatu tindakan sebelumnya;

2. Pendapat ahli atas dasar suatu tindakan yang harus dilakukan sebelum persidangan seperti pemeriksaan, penelitian, atau observasi.

Dalam kasus kekerasan psikis, khususnya pemeriksaan terhadap korban, pendapat ahli jiwa dapat diberikan di persidangan berdasarkan pengetahuan atau pengalaman ahli; namun demikian, pemeriksaan, penelitian, atau observasi terhadap korban harus dilakukan sebelum persidangan dilaksanakan guna menemukan adanya sebab trauma psikis yang dialami korban sebagai akibat dari perbuatan pelaku. Secara singkat dalam rangka pembuktian perkara tindak pidana kekerasan psikis dalam rumah tangga, adanya korelasi dan hubungan kausal antara sebab dengan akibat itulah yang menjadi fokus pemeriksaan di pengadilan; dan pemeriksaan ahli jiwa dilakukan sebelum persidangan.
Pentingnya pemeriksaan, penelitian, atau observasi terhadap korban, sebelum dilakukannya persidangan adalah untuk menyimpulkan adanya hubungan kausal antara perbuatan terdakwa dengan akibat yang ditimbulkannya, dalam hal ini perbuatan kekerasan psikis yang dilakukan oleh pelaku terhadap korban. Dalam Putusan Nomor 173/Pid.Sus/2014/PN.Lmj, pemeriksaan, penelitian, atau observasi terhadap korban $\mathrm{S}$ diperlukan sebelum dilakukannya persidangan untuk menyimpulkan adanya hubungan kausal antara perbuatan terdakwa AW dengan trauma yang dialami korban, sebagaimana dilakukan dalam Putusan Nomor 79/PID.SUS/2015/ PT.MDN dan Putusan Nomor 84/Pid.Sus/2017/ PN.Kng. Diagnosis ahli jiwa diperlukan sebelum dilakukannya persidangan, dan apabila diperlukan dimungkinkan untuk diberikan tindakan psikoterapi atau farmakoterapi terhadap korban.

Terkait dengan pemeriksaan ahli, Penjelasan Pasal 186 KUHAP menentukan bahwa: "keterangan ahli ini dapat juga sudah diberikan pada waktu pemeriksaan oleh penyidik atau penuntut umum yang dituangkan dalam suatu bentuk laporan dan dibuat dengan mengingat sumpah di waktu ia menerima jabatan atau pekerjaan; jika hal itu tidak diberikan pada waktu pemeriksaan oleh penyidik atau penuntut umum, maka pada pemeriksaan di sidang, diminta untuk memberikan keterangan dan dicatat dalam berita acara pemeriksaan."

Hasil pemeriksaan ahli jiwa, apabila merujuk pada Penjelasan Pasal 186 KUHAP, dapat diberikan pada waktu pemeriksaan oleh penyidik atau penuntut umum yang dituangkan dalam suatu bentuk laporan dan dibuat dengan mengingat sumpah pada waktu menerima jabatan atau pekerjaan. Dengan demikian, merujuk 
Pasal 186 KUHAP, hasil pemeriksaan ahli dapat diberikan secara tertulis dan secara lisan di persidangan.

Pemeriksaan psikolog forensik secara tertulis berupa hasil keterangan pemeriksaan psikologi; sedangkan hasil pemeriksaan psikiatri forensik disebut visum et repertum psychiatricum. Menurut Hiariej (2012: 107), jika seorang ahli memberikan keterangan secara langsung di depan sidang pengadilan dan di bawah sumpah, keterangan tersebut adalah alat bukti keterangan ahli yang sah; dan jika seorang ahli di bawah sumpah telah memberikan keterangan tertulis di luar persidangan dan keterangan tersebut dibacakan di depan sidang pengadilan, keterangan ahli tersebut merupakan alat bukti surat dan alat bukti keterangan ahli.

Visum et repertum psychiatricum dan keterangan hasil pemeriksaan psikologi sebagai alat bukti surat, isinya adalah keterangan ahli yang diberikan di bawah sumpah dan di luar sidang pengadilan. Sebagai alat bukti surat, baik visum et repertum psychiatricum maupun keterangan hasil pemeriksaan psikologi dapat diberikan sebelum dimulainya persidangan atau tahap pra-ajudikasi.

Apabila pada tahap pra-ajudikasi tidak dilakukan pemeriksaan ahli jiwa, maka sebenarnya hakim dapat memerintahkan untuk dilakukannya pemeriksaan kondisi kejiwaan korban dalam kasus tindak pidana kekerasan psikis; dalam hal ini secara teknis hakim berwenang penuh memerintahkan penuntut umum untuk melengkapi berkas dakwaannya. Pemeriksaan ahli jiwa yang tidak diberikan pada tahap pra-ajudikasi dalam proses pemeriksaan Putusan Nomor 173/Pid.Sus/2014/PN.Lmj, dalam pembuktiannya di persidangan seharusnya hakim dapat memerintahkan pada penuntut umum untuk dilakukannya pemeriksaan psikologi forensik atau psikiatri forensik terhadap korban $\mathrm{S}$.

Aspek-aspek klinis dalam pemeriksaan psikologi forensik menurut Kitaeff (2017: 25-26) secara umum meliputi hal-hal seperti kewarasan, kompetensi untuk menjalani persidangan, penyaringan psikologis prakerja untuk bidang pekerjaan penegakan hukum dan bidang-bidang pekerjaan berisiko tinggi lainnya, evaluasi fitness-for-duty, hipnosis, pembuatan profil psikologi, autopsi psikologis, evaluasi hak asuh anak, asesmen psikologi klinis umum, menangani pelaku penyerangan seksual dengan kekerasan, dan membantu orang-orang yang menjadi korban kejahatan dan trauma.

Merujuk pada pendapat Kitaeff, ruang lingkup pemeriksaan di dalam psikologi forensik, secara jelas nampak adanya interaksi dan interkoneksi antara psikologi dan hukum, khususnya dalam pemeriksaan korban kekerasan psikis dalam rumah tangga. Mengingat hakikat dari tujuan pemeriksaan perkara pidana, yaitu menemukan kebenaran materiel, oleh karena itu, pemeriksaan kejiwaan korban kekerasan psikis, yang berakibat pada trauma psikis seharusnya dilakukan dalam kasus kekerasan dalam rumah tangga sebagaimana ditentukan di dalam UndangUndang Nomor 23 Tahun 2004.

Adanya akibat trauma psikis dalam formulasi delik kekerasan psikis dalam rumah tangga menjadi titik kulminasi pembuktian perbuatan dan kesalahan terdakwa. Pemeriksaan terhadap korban oleh ahli jiwalah yang dapat mengungkap kebenaran materiel dalam perkara kekerasan psikis dalam rumah tangga. Pemeriksaan ahli jiwa, baik psikiater maupun 
psikolog yang menjadikan penilaian adanya trauma psikis memenuhi hakikat logis, rasional, dan ilmiah dalam pemeriksaan kasus perkara kekerasan psikis dalam rumah tangga.

Berbicara mengenai masalah kekerasan psikis, sebenarnya kita sedang berhadapan dengan dua disiplin ilmu yang berbeda ranahnya, yaitu hukum dan psikologi dan/atau psikiatri yang berada pada ranah ilmu jiwa. Memang, ada titik temu antara hukum dengan ilmu jiwa, bahkan Constanzo (2008: 3-4) menyatakan, bahwa psikologi dan hukum secara abstrak, tampak seperti pasangan yang sempurna, karena keduanya berusaha menyelesaikan masalah manusia serta memperbaiki kondisi manusia.

Menurut Carroll (dalam Constanzo, 2008: 15), hukum menekankan penerapan prinsipprinsip abstrak pada kasus-kasus tertentu. Dengan bantuan disiplin psikologi dan/atau psikiatri itulah, dalam menghadapi kasus hukum yang konkret, kebenaran yang terjadi dapat diungkap, kemudian berbasis pada hasil diagnosis dari pemeriksaan psikologi forensik dan/atau psikiatri forensik, diharapkan secara ideal tujuan kebenaran materiel di dalam pemeriksaan perkara pidana akan dapat diwujudkan, atau setidaknya dapat mendekati kebenaran yang ilmiah.

\section{KESIMPULAN}

Kesimpulan yang dapat diambil dari kajian Putusan Nomor 173/Pid.Sus/2014/PN.Lmj yang fokus utamanya mengenai eksistensi pemeriksaan ahli jiwa dalam kasus kekerasan psikis dalam rumah tangga, adalah sebagai berikut:

Perkara Nomor 173/Pid.Sus/2014/PN.Lmj memutus perkara tindak pidana kekerasan psikis dalam rumah tangga sebagaimana ditentukan di dalam Undang-Undang Nomor 23 Tahun 2004. Formulasi kekerasan psikis dalam rumah tangga, ditentukan sebagai delik materiel yang melarang adanya akibat penderitaan psikis tertentu pada korban. Kedudukan ahli jiwa sangatlah urgen dalam membuktikan adanya hubungan kausal antara perbuatan pelaku yang berdampak psikis atau trauma psikis pada korban. Tanpa pemeriksaan ahli jiwa terhadap korban $\mathrm{S}$, maka adanya hubungan kausal antara trauma psikis sebagai akibat perbuatan terdakwa AW tidaklah dapat dibuktikan.

\section{DAFTAR ACUAN}

Badriyah, S.M. (2016). Sistem penemuan hukum dalam masyarakat prismatik. Jakarta: Sinar Grafika.

Constanzo, M. (2008). Soetjipto, H.p., \& Soetjipto, S.M. (Eds.). Aplikasi psikologi dalam sistem hukum. Yogyakarta: Pustaka Pelajar.

Danis, D. (tt.). Kamus istilah kedokteran. Jakarta: Gita Media Press.

Diantha, I.M.P. (2016). Metodologi penelitian hukum normatif dalam justifikasi teori hukum. Jakarta: Prenada Media Group.

Djamali, R.A. (1984). Psikologi dalam hukum. Bandung: Armico.

Gerungan, W.A. (2009). Psikologi sosial. Bandung: Refika Aditama.

Hiariej, E.O.S. (2012). Teori \& hukum pembuktian. Jakarta: Erlangga. (2016). Prinsip-prinsip hukum pidana edisi revisi. Yogyakarta: Cahaya Atma Pustaka. 
Kitaeff, J. (2017). Soetjipto, H.P., \& Soetjipto, S.M. (Eds.). Psikologi forensik. Yogyakarta: Pustaka Pelajar.

Mappiase, S. (2015). Logika hukum pertimbangan putusan hakim. Jakarta: Prenadamedia Group.

Marwan \& Jimmy. (2009). Kamus hukum. Jakarta: Reality Publisher.

Marzuki, P.M. (2014). Penelitian hukum edisi revisi. Jakarta: Prenadamedia Group.

Meliala, A. (2008, Januari). Kontribusi psikologi dalam dunia peradilan: Dimana \& mau kemana. Indonesian Journal of Legal and Forensic Sciences (IJLFS), 1(1), 56-59.

Ohoiwutun, Y.A.T. (2015, April). Kesaksian ahli jiwa dalam pertanggungjawaban pidana penganiayaan berat: Kajian Putusan Nomor 210/Pid.B/2005/PN.RKB. Jurnal Yudisial, $8(1), 1-22$.

(2016a). Ilmu kedokteran forensik (Interaksi \& dependensi hukum pada ilmu kedokteran). Yogyakarta: Pohon Cahaya.

. (2016b, April). Urgensi bedah mayat forensik dalam pembuktian tindak pidana pembunuhan: Kajian Putusan Nomor 79/ Pid.B/2012/PN.BGR. Jurnal Yudisial, 9(1), 73-92.

(2017, April). Penerapan prinsip "kepentingan terbaik bagi anak" dalam kasus tindak pidana narkotika: Kajian Putusan Nomor 229/Pid.B/2012/PN.Jpr. Jurnal Yudisial, 10(1), 39-57.

Reber A.S., \& Reber E.S. (2010). Santoso, Y. (Ed.). Kamus psikologi. Yogyakarta: Pustaka Pelajar.

Rodliyah \& Salim H.S. (2017). Hukum pidana khusus unsur \& sanksi pidananya. Depok: Rajawali Pers.
Santoso, H.M.A. (2014). Hukum, moral, \& keadilan sebuah kajian filsafat. Jakarta: Kencana.

Sofian, A. (2018). Ajaran kausalitas hukum pidana. Jakarta: Kencana.

Sudarto. (1986). Hukum \& hukum pidana. Bandung: Alumni. 